\title{
RECENT DEVELOPMENTS REGARDING SOUTH AFRICAN COMMON AND CUSTOMARY LAW OF SUCCESSION
}

\author{
MC Schoeman-Malan
}

\section{Background to the South African law}

South African law consists of the common law (rules set down by the old Roman-Dutch authorities as developed by court decisions) and statutory law (acts of the national and provincial legislatures as well as governmental regulations). ${ }^{1}$ The law in general is not codified and, like English law, must be sought in court decisions and individual statutes. South African law is described by Palmer $^{2}$ as follows:

In the Cape Colony, a mixed jurisdiction came about after the Dutch - who had transplanted the law of the seventeenth-century Holland to the Cape of Good Hope soon after setting up a supply base there on 6 April 1652 - handed over authority in 1806 to the English who began introducing elements of their own legal system.

In South African law, and particularly in the Cape Colony, the law of succession was inspired by both English law and Roman-Dutch law. ${ }^{3}$ With regard to law of succession Corbett and Others ${ }^{4}$ explain the development as follows:

In South Africa the principles and main institutions of the law of testamentary succession are Roman-Dutch, but, as regards the

* $\quad$ BA (Law) LLB LLD (UP). Professor in Private Law, University of Pretoria. This article is based on a paper delivered at the XVII ${ }^{\text {th }}$ AIDC Congress of Comparative Law (16-22 July 2006).

1 Barratt and Snyman 2002 LLRX http://www.Ilrx.com/ 11 Dec.

2 Palmer Mixed jurisdictions 83. See also Tetley 1999 ULR 7 http://www.unidroit.org/ 20 Apr.

3 For the historical background of the Dutch law, the French Code Civil, the "Germaanse Recht", the "Nederlandse Burgerlijk Wetboek 1838" and the "Nieuw Burgerlijk Wetboek Erfrecht" see Van der Burght and Ebben Nederland Erfrecht 7.

4 Corbett et al Succession 2; Palmer Mixed jurisdictions 119. 
execution and interpretation of wills, our law has been strongly influenced by the law of England. ${ }^{5}$

Not all South Africans are of European origin. The population consists of people of diverse ethnic and cultural origin. Several black tribes resided here long before the incursion by Europeans. During the later period of English governance a system of 'native administration' was established. According to this policy, indigenous people could rule themselves according to indigenous law in certain matters, for example rules of marriage and succession. Matters of customary law were heard by traditional leaders and headmen, with a right of appeal to the Native Appeal Court, staffed by commissioners.

Today, South Africa retains a pluralistic legal system, with customary law remaining a legal system for those who wish to be subject to it. ${ }^{6}$ In 1994 South Africa became a constitutional state and the Constitution of South Africa, $1996^{7}$ has been the supreme law since. ${ }^{8}$ The rules of customary law may not, however, conflict with the Constitution. Section 211 of the Constitution reads as follows:

\section{Recognition}

(1) The institution, status and role of traditional leadership, according to customary law, are recognised, subject to the Constitution.

(2) A traditional authority that observes a system of customary law may function subject to any applicable legislation and customs, which includes amendments to, or repeal of, that legislation or those customs.

(3) The courts must apply customary law when that law is applicable, subject to the Constitution and any legislation that specifically deals with customary law.

5 See Van der Merwe and Rowland Succession 21 for the development of the law of intestate succession.

6 Kerr 2005 (2) SPECULUM JURIS 181 and Kerr 2006 (1) SPECULUM JURIS 1.

7 In terms of S 1(2) of the Citation of Constitutional Laws Act 5 of 2005 which came into operation on 27 June 2005 all references to the Constitution of the Republic of South Africa Act 108 of 1996, have been replaced by the Constitution of South Africa, 1996.

8 Barratt and Snyman supra $\mathrm{n} 1$. 
Section 30 provides that everyone has a right to participate in the cultural life of their choice and section 31 provides that persons belonging to a cultural community may not be denied the right, with other members of that community, to enjoy their culture. A group's right to practice their culture may not be used as a reason to deprive an individual of his or her fundamental rights. ${ }^{9}$

\section{Background to recent law reform in South African law}

This article will concentrate on the development in the common law of succession and administration of estates versus the customary law of succession and inheritance as well as the winding up of estates pursuant to constitutional tendencies, case law, as well as statutory reform over the last ten years.

During the 1980s and 1990s some law reform took place in South Africa regarding the law of succession. Intestate succession was reformed with the promulgation of the Intestate Succession Act 81 of 1987 [henceforth Intestate Succession Act], which was in fact a codification to a great extent of the common law of intestate succession. ${ }^{10}$ The law of testate succession also came under review and resulted in the Law of Succession Amendment Act 43 of 1992 which brought about fundamental changes to both the Intestate Succession Act as well as the Wills Act 7 of 1953 [henceforth Wills Act]. ${ }^{11}$

Initial reform of the South African law of succession did not consider the differences between the common law of succession and the customary law of succession and inheritance applicable to black South Africans living mainly in rural areas. $^{12}$ The principles of customary law of succession and inheritance

9 SALRC 2004 Customary Law of Succession par 3.1.8. The South African Law Reform Commission (SALRC) was previously known as South African Law Commission (SALC).

10 Implemented on 18 March 1988. See Van der Merwe and Rowland Succession 25 for the statutory and common law position before 1988. Some common law principles were retained.

11 Implemented on 1 October 1992. The Wills Act 7 of 1953 (henceforth Wills Act) and common law (also known as civil law) prevail before the amendments.

12 The object of customary law of succession was the continuation of the family unit. 
have become a contentious issue since the advent of the new human rights dispensation in South Africa. ${ }^{13}$ The underlying differences in the two systems are based on the unequal treatment of men and women in customary law and it raises questions regarding the harmonising of elements of black intestate succession with the equality clause contained in the Bill of Rights. ${ }^{14}$

For quite some time after 1992 the South African Law Reform Commission ${ }^{15}$ (SALRC) investigated aspects of customary law which included inheritance and customary marriages. ${ }^{16}$ On 15 November 2000 the Recognition of Customary Marriages Act 120 of 1998 came into operation. The SALRC also has, since 1996, been investigating the possible harmonisation of the law of succession (statutorily and common law regulated) and customary or indigenous law of succession in accordance with the new constitutional order. ${ }^{17}$ The Commission launched an Issue Paper entitled Succession in Customary Law in 1998 and published Discussion Papers in 2000 and 2001. ${ }^{18}$ The SALRC continued its work and in April 2004 completed a further report entitled "Customary Law of Succession". This report was completed after the High Court judgment in Bhe $v$ Magistrate, Khayelitsha, ${ }^{19}$ but before the Constitutional Court judgment in the same case. $^{20}$ The Report was submitted to the Minister of Justice and Constitutional Development, but was never formally published. ${ }^{21}$

13 From 1994 onwards. See the interim Constitution of the Republic of South Africa Act 200 of 1993 and the Constitution of the Republic of South Africa 1996.

14 De Waal and Schoeman-Malan Succession 33.

15 SALRC 2004 Customary Law of Succession. See also SALC 1998 Report on Customary Marriages.

16 As the law of succession is inextricably linked to the law with regarding marriages.

17 SALRC 1999 Harmonisation of the Common Law and Indigenous Law; SALRC 2004 Customary Law of Succession.

18 SALRC 2000 Customary Law: Succession Discussion and SALRC 2001 Customary Law: Administration of Estates.

19 Bhe v Magistrate, Khayelitsha 2004 (2) SA 544 (C); 2004 (1) BCLR 27 (C).

20 Bhe v Magistrate, Khayalitsha; Shibi v Sithole; South African Human Rights Commission $v$ President of the Republic of South Africa 2005 (1) 580 (CC) [henceforth Bhe-case].

21 SALRC 2004 Customary Law of Succession. In ch 7 one can find a summary of a proposed Draft Bill. They debated the question whether customary rules of succession are appropriate to modern social conditions and serve the purposes expected of the law of succession in the light of the new human rights dispensation. In par 2.3.13 of the report the SALRC stated: "There can be no doubt that customary law in South Africa, as in other Southern African countries, is responding in a pragmatic fashion to social needs." 
For purposes of law reform, it is important to take note of changed social conditions such as urbanisation, but no law reform can take place if it is not within the boundaries of the new constitutional order. Not only is gender discrimination prohibited in section 9 of the Constitution, but it is reinforced by South Africa's obligation under the International Convention on the Elimination of All Forms of Discrimination against Women (CEDAW) ${ }^{22}$ and more recently the Promotion of Equality and Prevention of Unfair Discrimination Act 4 of $2000 .^{23}$

The Commission considered the following divergent approaches to the problem:

(i) That customary law of succession should be abolished, and that a single legal regime that would eliminate any sense of racial discrimination and might promote national unity be adopted. ${ }^{24}$

(ii) That customary law should be retained somehow. An option should be created for people who wish to continue practicing customary law and to incorporate those aspects of customary law and values that are compatible with the Constitution. ${ }^{25}$

The Commission believes that in order to comply with the constitutional value of equality it is imperative to ensure that the law relating to inheritance and customary law does not prejudice certain people, particularly widows, daughters and male children who are not first born. ${ }^{26}$ They recommend that the Intestate Succession Act should be used as a vehicle to go part of the way. ${ }^{27}$

Signed on 29 January 1993. S 14 and 16(1)(h).

See s 8(c) and (d).

24 The South African system of legal pluralism (dual legal system) consists of common law and statutory developments versus a number of closely related customary laws. Comparative studies indicate that where there is a plural or dual legal system people are allowed to choose the applicable system. In South Africa unfortunately the application of customary law depends on a person's race and thus gives the appearance of racial discrimination. Par 4.1.3 and 1.6.10.

25 SALRC 2004 Customary Law of Succession par 1.5.3

26 Conclusion in par 1.7.1. See also par 6.1.

27 Par 1.7.2. They have recommended that the intestate estates of Africans who were previously excluded from the application of the Intestate Succession Act should devolve in 
In its study the SALRC looked into reform in African countries such as Malawi, Ghana, Zimbabwe and Zambia, which according to the Commission, present useful models for South Africa. ${ }^{28}$ It was mentioned in concluding that the purpose of succession is that the property of the deceased should be left to the use and benefit of his or her closest relatives or those who were dependent upon him or her during his or her lifetime. ${ }^{29}$

The SALRC also examined certain aspects of the administration of estates. ${ }^{30}$ It was decided not to proceed with an earlier Customary Law of Succession Amendment Bill ${ }^{31}$ after it had received a hostile reaction, especially from traditional leaders. ${ }^{32}$

As far as the winding-up of deceased estates is concerned, the Commission's research shows that it is normally regulated privately by the deceased's family. The family would meet after someone's death and distribute the estate and see to the needs of the widow and children. Unless there is a serious disagreement at this meeting, no outside authority is involved. Family councils has considerable discretion in deciding how best to secure the welfare of the surviving dependants. ${ }^{33}$

accordance with their proposed Reform of the Customary Law of Succession Act. See par 6.2.6, annexure A and par 6.3.6.

28 SALRC 2004 Customary Law of Succession 2.4.2. The Commission got insight in relation to the changes made but also foresaw problems with the implementation of the new laws. See also Bhe (supra) par [192-211].

29 SALRC 2004 Customary Law of Succession par 2.5.

30 SALRC 2000 Customary Law: Succession Discussion; SALRC 2003 Draft Interim Report.

31 Customary Law of Succession Amendment Bill 109 of 1998.

32 SALRC 2004 Customary Law of Succession par 1.1.4. The traditional healers had concerns about what they perceived to be an attempt to 'westernise' the customary law of succession. 
In the meantime, aspects of the administration of estates of deceased blacks also were challenged in court on constitutional grounds ${ }^{34}$ and the Legislature was forced to make some changes.

A further report on Administration of Estates Act 66 of $1965^{35}$ [henceforth Administration Act] was then published in October 2005. The recommendations will be discussed later.

\section{Principles of common and customary law of succession}

\subsection{Common law ${ }^{36}$}

\subsubsection{General}

The principles of common law of intestate and testate succession, which apply mainly to white, coloured and Indian South Africans, are rather easy to find. ${ }^{37}$

\subsubsection{Intestate succession}

If a white person dies intestate, the Intestate Succession Act reflects the following principles: ${ }^{38}$

(a) the circle of potential intestate heirs can be easily identified and is drawn comparatively tight; ${ }^{39}$

(b) men and women (spouses) receive equal treatment; and

(c) first born children do not receive special treatment.

34 Zondi v President of the Republic of South Africa 2000 (2) SA 49 (N); Moseneke $v$ The Master 2001 (2) SA 18 (CC); Bhe v Magistrate, Khayalitsha; Shibi v Sithole; South African Human Rights Commission v President of the Republic of South Africa supra $\mathrm{n} 20$.

35 SALRC 2005 Administration of Estates. Closing date for comment was 18 Nov 2005.

36 Referring to the Roman-Dutch law (common law) as developed in South Africa by statutory intervention.

37 Intestate Succession Act and Wills Act. There are also standard works on the law of succession: see Corbett et al Succession and De Waal and Schoeman-Malan Succession.

38 See s 1(1)(a)-1(1)(f). These provisions also govern the situation where s 23 of the Black Administration Act 38 of 1927 [henceforth BAA] is not applicable. In Roman-Dutch law the surviving spouse had no succession right $a b$ intestate. See Van der Merwe and Rowland Succession 67 and the footnotes.

39 See De Waal and Schoeman-Malan Succession 32. 
In terms of section $1(4)(b)$ the Intestate Succession Act is not applicable if -

(i) there is a will dealing with specific parts of the estate (the rules of testate succession will then apply); or

(ii) section 23 of the Black Administration Act 38 of 1927 (BAA) is applicable. ${ }^{40}$

\subsubsection{Testate succession}

The law of testate succession is found in the Wills $\mathrm{Act}^{41}$ and common law principles. $^{42}$

The common law of testate succession is based on the principle of freedom of testation. In terms of section 25(1) of the Constitution -

.... [n]o one may be deprived of property except in terms of law of general application, and no law may permit arbitrary deprivation of property.

The provision guarantees the right to private property and it includes the right to dispose of one's property. The institution of succession is thus guaranteed. It allows individuals to dispose of their property to whomever they want to. ${ }^{43}$ According to this principle, testators are free to dispose of their assets regardless of the interest of intestate heirs.

Effect will not be given to testamentary provisions if compliance with such provisions are contra bonos mores or against public policy. Some limitations are recognised that are based, in general, on economic or social considerations. $^{44}$

40 S 23 of the BAA makes provision for the application of either black customary law or a system of succession, depending on the nature of the assets concerned, explained in regulations pertaining to the Act. See regulations for the Administration and Distribution of the Estates of Deceased Blacks GN R200 of 1987, henceforth Reg GN R200 of 1987. Amended by GN R1501 of 2002.

41 As amended by the Law of Succession Amendment Act 43 of 1992.

42 Corbett et al Succession 33-34 and De Waal and Schoeman-Malan Succession 35.

43 A power that was derived from the principle of absolute ownership of property. Corbett et al Succession 2.

44 Corbett et al Succession 46-48. De Waal and Schoeman-Malan Succession 4. 
The limitations on freedom of testation can be reconciled with the fundamental rights in section 36 of the Constitution. A complete disinheritance would be respected subject to a dependant's claim for maintenance. ${ }^{45}$ It seems though that the Bill of Rights might have an influence on the principle of freedom of testation. ${ }^{46}$ A condition linked to a consideration mentioned in section 9(3) of the Constitution could be declared invalid. ${ }^{47}$ In terms of section 9(3) and 9(4) no person may directly or indirectly discriminate unfairly against anyone on the basis of considerations which include race, gender, sex, pregnancy, marital status, ethnic or social origin, colour, sexual orientation, age and culture. ${ }^{48}$

\subsection{Customary law of succession and inheritance}

\subsubsection{General}

The customary law of succession and inheritance, which applies in South Africa to blacks only for the bigger part, initially was uncodified, although some codification and changes had been brought about by means of legislation. ${ }^{49}$ There are also differences between various communities and tribes. ${ }^{50}$ Some general principles may however be identified. ${ }^{51}$ Indigenous law is mainly concerned with:

- inheritance of property ${ }^{52}$ (as far as inheritance is concerned a distinction is made between general, house property and personal property) ${ }^{53}$ and

45 See De Waal and Schoeman-Malan Succession 4 and Maintenance of the Surviving Spouses Act 27 of 1990.

46 Minister of Education v Syfrets Trust 2006 (4) SA 205 (C).

47 De Waal and Schoeman-Malan Succession 6.

48 The equality clause. See also Corbett et al Succession 47-48.

49 Olivier et al Indigenous Law 240-244. See s 23 of the BAA; S 7(a) was repealed by the Administration of Estates Amendment Act 47 of 2002 (henceforth Administration Act). Reg GN R200 of 1987 - amended by GN R1501 of 2002; now repealed by the Repeal of Black Administration Act and Amendment of Certain Laws Act 28 of 2005. See also the Black Areas Land Regulations (Procl R188 of 1969).

50 SALRC 2004 Customary Law of Succession par 2.2.1. Also see Olivier et al Indigenous Law 222-238.

51 See henceforth Bekker et al Introduction $109 \mathrm{ff}$ and Olivier et al Indigenous Law par 222238.

52 Land and livestock.

53 Ownership is not individual but collective. 
- $\quad$ succession to the status of the deceased ${ }^{54}$ (as there are different tribes there are detailed differences in applying the general principle throughout the country.)

\subsubsection{Intestate succession}

Section 23 of the BAA used to rule customary testate and intestate succession. ${ }^{55} \mathrm{~A}$ black person's intestate estate would, therefore, have been divided by either customary law or in terms of the regulations promulgated in terms of the Act. Regulation GN R200 of 1987 was issued in terms of section 23(10) of the BAA. ${ }^{56}$ If there was property which section 23 did not divide and if there was no will, the property had to devolve according to regulation 2 . This regulation gave legislative recognition to male primogeniture.

The order of customary succession is based on three principles: ${ }^{.57}$

- a family unit is a cultural concept in which the material needs of the component family members are not the main ingredients;

- primogeniture, ${ }^{58}$ and

- the male line of descent. ${ }^{59}$

If the deceased was the holder of a letter of exemption from customary law issued by the President, his or her property had to devolve according to common law. ${ }^{60}$ The form of marriage a person entered into also was important to determine if customary ${ }^{61}$ or common law of succession would be applicable.

54 SALRC 2004 Customary Law of Succession par 2.2.2.

55 As seen above in terms of $\mathrm{s} 1(4)(b)$ the Intestate Succession Act is not applicable.

56 S 23 and Reg GN R200 of 1987.

57 SALRC 2004 Customary Law of Succession par 2.2.5. Normally privately regulated by the deceased's family.

58 SALRC 2004 Customary Law of Succession par 2.2.4.

59 SALRC 2004 Customary Law of Succession par 2.2.3. Both men and the first born of a family enjoy precedence.

$60 \mathrm{~S} 31$ of the BAA.

61 The Recognition of Customary Marriage Act 120 of 1998 defines a customary marriage as a marriage concluded in accordance with customary law. 
If the deceased concluded only a civil marriage ${ }^{62}$ in community of property, his

or her estate would devolve in terms of the common law of succession. ${ }^{63}$

To the extent set out above, it was a system of succession and inheritance which was both unconstitutional and discriminatory.

\subsubsection{Testate succession}

In testate succession a black person was restricted to making a will in certain ways. ${ }^{64}$ Freedom of testation was limited to certain types of property by section 23 of the BAA as follows:

1. All movable property belonging to a black and allotted to him or accruing under black law or custom to any woman with whom he lived in a customary union, or to any house (a customary marriage created a 'house') shall upon his death devolve and be administered under black law and custom;

2. All land in a tribal settlement held in individual tenure upon quitrent conditions by a black shall devolve on his death upon one male person, to be determined in accordance with tables of succession prescribed under subsection (10); ${ }^{65}$

3. All other property of whatsoever kind belonging to a black shall be capable of being devolved by a will.

62 A civil marriage in terms of South African common law. See the Matrimonial Property Act 88 of 1984. As for civil marriages of blacks, those entered into between 1 Jan 1929 and 1 Dec 1988 were almost all with complete separation of property, but with marital power in the husband. Only marriages entered into after 1 Dec 1988 have been governed by the same property regime as marriages of other South Africans. See also Marriage and Matrimonial Property Amendment Act 3 of 1988.

63 Reg 2(c). The Intestate Succession Act would apply. Reg 2 has, however, been declared unconstitutional and invalid in Zondi v President of the Republic of South Africa (supra $\mathrm{n}$ 34) and Bhe v Magistrate, Khayalitsha; Shibi v Sithole; South African Human Rights Commission v President of the Republic of South Africa (supra $\mathrm{n} 20$ ).

64 SALRC 2004 Customary Law of Succession par 2.2.1 n 49 and s 23 of the BAA.

65 Quitrent tenure was granted in some districts in the Eastern Cape and the Umzinto district in KwaZulu-Natal. It has since been upgraded to full ownership in terms of the upgrading of Land Tenure Rights Act 112 of 1991, but the concomitant rules of succession are only now in the process of repeal. 
While customary law differs in details from one community to another, there are certain basic principles regulating succession:

- Individuals are not free to decide how and on whom their estates will devolve. ${ }^{66}$

- Customary property, which is mainly land and livestock, attracts group interest and cannot be devolved by will.

There also are differences between succession in a monogamous household ${ }^{67}$ and in a polygamous household. ${ }^{68}$ Studies show that there are, furthermore, differences between the 'official' and 'living' versions of customary law. ${ }^{69}$

As nothing was forthcoming from the SALRC, the Courts were asked to intervene and develop a system consonant with the Constitutional imperative or to declare discriminatory rules of customary law of succession and inheritance unconstitutional and therefore invalid.

\subsection{Administration of estates}

The winding up and administration of estates also could be divided in two categories, also based on a differentiation between races. The Master had jurisdiction over the testate estates of deceased whites, coloureds, Indians and blacks $^{70}$ and magistrates had jurisdiction over the intestate estates of blacks who resided within their areas of jurisdiction. The power of the Master to administrate intestate black estates was excluded in terms of section 23(7)(a) of the $B A A$ and section $4(1 \mathrm{~A})$ of the Administration Act, whilst the power to Succession par 2.3. The official version of customary law seems to encourage the idea of succession to status and inheritance of property while the living indigenous law gives evidence of distribution of property to individuals. See also Bekker and Maitufi 1992 JJS 47.

70 House property and quitrent land were excluded in terms of $s 23$ (9) of the BAA from testamentary disposition. 
administer intestate black estates was confined to a magistrate in terms of regulation 3(1) of GN R200 of $1987 .^{71}$

\section{Summary of main differences between customary and common law}

The law of succession (applicable to whites, coloureds and Indians and, to a lesser extent, some blacks ${ }^{72}$ ) on the one hand and the customary or indigenous laws (applicable to blacks only) on the other hand in fact and practice differentiated between different races.

4.1 A black person's freedom of testation was restricted to some extent. A black person could not bequeath whatever he wanted. If there was property which did not fall within the restriction, a black person could have made a will and there was no difference in this regard between the testate estate of a black and white person. It means that persons who had concluded a civil marriage, but never a customary marriage and unmarried men and women, in so far as they were individual holders of rights to property, were allowed to dispose of their estates by means of a will. Persons who were exempted from customary law were also free to dispose of their property in this manner.

4.2 As far as the law of intestate succession went, the differentiation becomes prominent in the Intestate Succession Act. ${ }^{73}$ Section 23 of the BAA had preference in respect of black persons and provided for the application of either (a) black customary law or (b) a system of succession set out in regulations promulgated in terms of the BAA. ${ }^{74}$ It regulated succession among persons living under customary law.

71 See discussion below where s 23(7)(a) and reg 3(1) were found to impose differentiation on grounds of race, ethnic origin and colour.

72 Reg 2 and Kerr 2005 SPECULUM JURIS 181 and Kerr 2006 SPECULUM JURIS 1.

73 As amended in 1992 by the Law of Succession Amendment Act 43 of 1992.

74 Reg GN R200 of 1987. 
4.3 The Administration Act regulates various aspects regarding the winding up and administration process of estates. This included all testate (black and white) estates, but intestate estates of whites only. The administration of all intestate estates of black persons resorted under the BAA and the Regulations promulgated in terms thereof. ${ }^{75}$

4.4 Furthermore, until recently the intestate estates of black persons were administered by a magistrate, ${ }^{76}$ while the estates of all other race groups, including testate estates of black persons, were administered by executors under the supervision of the Master of the High Court. ${ }^{77}$

Differences that amounted to discrimination were challenged in the Constitutional Court regarding-

- Aspects of intestate succession; ${ }^{78}$

- Aspects of the administration of black intestate estates; ${ }^{79}$

- An African person's freedom of testation and freedom of testation in general. $^{80}$

\section{Recent changes as a result of judicial intervention}

As seen above, indigenous (customary) law in principle considers the concept of family in a wider context; ${ }^{81}$ it gives recognition to the rule of male primogeniture and consequently, the first born son in a family enjoys precedence. ${ }^{82}$ While the SALRC was investigating the current situation people

75 Reg GN R200 of 1987 issued in terms of s 23(10) of the BAA.

76 Reg 3(1) of Reg GN R200 of 1987.

77 S 23(7)(a) of the BAA excluded the Master's authority to administer intestate estates of black persons.

78 See discussion below and Zondi v President of the Republic of South Africa (supra n 34).

79 Reg 3(1) provided that an intestate estate of a black person had to be administered by a magistrate and not under supervision of the Master. See Moseneke $v$ The Master (supra $\mathrm{n}$ 34).

80 Bhe-case (supra n 20) and par 5 below.

81 De Waal and Schoeman-Malan Succession 32.

82 Bekker et al Introduction 109. 
started to rely on the courts for legal assistance. The Constitutional Court ruled that most of the differences between the common law and customary law were unconstitutional and the legislature revoked existing and adopted new legislation. ${ }^{83}$

\subsection{Intestate succession: case law}

\subsubsection{Mthembu v Letsela ${ }^{84}$}

In Mthembu $v$ Letsela the dispute revolved around the constitutionality of the customary law rule of succession which was based on male primogeniture preventing women from inheriting upon intestacy. ${ }^{85}$ The Supreme Court of Appeal refused an application that the court should develop the customary law in terms of the Interim Constitution ${ }^{86}$ in a way that would not differentiate between men and women. The judge, however, observed as follows at par [40]:

Any development of the rule would be better left to the Legislature after a full process of investigation and consultation, such as is currently being undertaken by the Law Commission.

\subsubsection{Zondi v President of the Republic of South Africa ${ }^{87}$}

In Zondi v President of the Republic of South Africa the deceased who was married and had two illegitimate children, died intestate in 1995. The marriage was not one in community of property in terms of section 22(6) of (the since

83 It should be mentioned that the rule of male primogeniture was not merely a crude form of male pre-eminence. The heir stepped into the shoes of the deceased family head and became responsible for the maintenance and welfare of the family.

84 Mthembu v Letsela 1997 (2) SA 936 (T) and 1998 (2) SA 675 (T) and 2000 (3) SA 867 (SCA).

85 In Nwamitwa v Phillia 2005 (3) SA 536 (T) the Court, however, stated that a Thonga woman could not succeed as traditional leader as it was not in accordance with the custom of the specific community. It was found that such practice was not in conflict with the Constitution.

86 Constitution of the Republic of South Africa Act 200 of 1993.

87 Supra n 34. 
repealed) $\mathrm{BAA}^{88}$ His estate therefore fell to be administered in terms of regulation $2,{ }^{89}$ that is, in accordance with customary law. Regulation 2 distinguished between rules of succession applicable to different marriages. In terms of the regulation, the deceased's brother would become the heir, and the illegitimate children would not inherit. The applicant sought an order declaring regulation 2 unconstitutional.

The court held that regulation 2 was unconstitutional to the extent that it distinguished, for purposes of intestate succession, between the estate of an African who was a partner in a section 22(6) marriage (that is, a marriage out of community of property) on the one hand, and the estate of an African who was a partner in a marriage in community of property or a marriage in terms of an ante-nuptial contract on the other hand. ${ }^{90}$

In granting the order, it was held that for the purposes of intestate succession the regulations distinguished between marriages concluded out of community of property, those entered into in terms of an ante-nuptial contract and those concluded in community of property. The court held that the constitutional prohibition on unfair discrimination in section 9 lies at the heart of the Constitution. $^{91}$ Furthermore, it found that regulation 2 offends against the equality provisions of the Constitution as children, both legitimate and illegitimate, of a deceased African person married by ante-nuptial contract or in community of property would qualify to inherit the estate, while the illegitimate children of persons in the same position as the deceased would not. The court found that it was grossly discriminatory and should be struck down, thus conferring on all illegitimate children the same succession rights. ${ }^{92}$

88 In terms of s 22(6) a black person could enter into one of three types of marriage (i) by ante-nuptial contract; (ii) in community of property and (iii) out of community of property.

89 Reg GN R200 of 1987.

90 S 22(6) was revoked by s 1(e) of the Amendment Act on Marriages Act 3 of 1988. See SALRC 2004 Customary Law of Succession par 3.2.17.

91 Fraser v Children's Court, Pretoria North 1997 (2) SA 261 (CC), President of the Republic of South Africa \& Anor v Hugo 1997 (4) SA 1 (CC).

92 This approach is in line with a 9 of the European Convention on the legal status of children born out of wedlock 1975, which provides that: "A child born out of wedlock shall have the same rights of succession in the estate of its father and its mother and of a member of its father's or mother's family as if it had been born in wedlock." 


\subsubsection{Moseneke $v$ The Master ${ }^{93}$}

In Moseneke $v$ The Master a retired person died without leaving a will. His estate included immovable property, motor vehicles, shares, unit trusts and insurance policies. He was survived by his widow and four sons. ${ }^{94}$ His estate was reported to the Master of the High Court in terms of the Administration Act. Under the BAA, the Master's office did not have the power to supervise the administration of intestate estates of black people, although the office administered all other intestate estates. Accordingly, the Master referred the estate to the magistrate in Pretoria, to be dealt with in terms of the BAA. ${ }^{95}$

The case did not deal with succession, although the Women's Legal Centre Trust applied for and was granted the right to make written and oral submissions as amicus curiae. ${ }^{96}$ They contended that in the case of intestate succession of deceased Africans, race, gender and culture interacted in a way which discriminated directly and indirectly against African women. ${ }^{97}$ The court found that it offended that people were still treated as 'blacks' rather than ordinary persons and that it is in conflict with the establishment of a non-racial society. ${ }^{98}$ The court stated clearly that it will not readily accept statutory provisions that discriminate between races. ${ }^{99}$ The court was sympathetic towards the fate of African women. ${ }^{100}$

\subsubsection{Bhe v Magistrate, Khayelitsha ${ }^{101}$}

Initially in Bhe $v$ Magistrate, Khayelitsha the applicant and the deceased initially lived together as husband and wife for a period of 12 years. Two minor children were born out of the relationship and being minors females, were assisted by

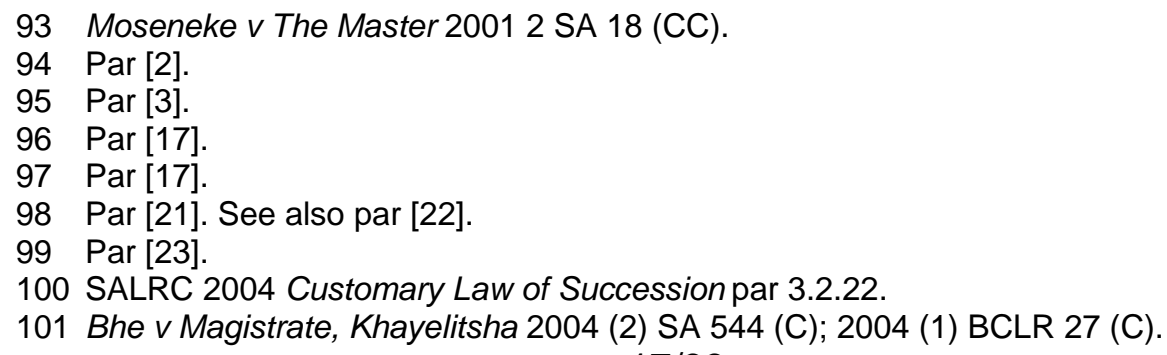


their mother in the application. The deceased had died without leaving a will. The father of the deceased claimed that he was the intestate heir of the deceased by virtue of the African customary law and, therefore, was entitled to inherit the property of the deceased, which he intended to sell.

It was held that section 23(10)(a), (c) and (e) of the BAA had to be declared unconstitutional and invalid and that regulation 2(e) of the Regulations for the Administration and Distribution of the Estates of Deceased Blacks consequently also was invalid. ${ }^{102}$ Further, that section $1(4)(b)$ of the Intestate Succession Act had to be declared unconstitutional and invalid insofar as it excluded from the application of section 1, any estate or part of any estate in respect of which section 23 of the BAA applied. ${ }^{103}$ Until the aforegoing defects were corrected by competent legislature, it had to be declared that the distribution of intestate black estates was governed by section 1 of the Intestate Succession Act. ${ }^{104}$

The only reason why the first two applicants could not inherit from their father's estate was because they were black and female. This per se was discrimination on grounds of race and gender. It was prima facie unfair and therefore offended against the provisions of sections 9(1) and (3) of the Constitution. The court was thus bound to declare such law unconstitutional and invalid. ${ }^{105}$

The court decided that African females, irrespective of age or social status, were entitled to inherit from their parents' intestate estate like any male person. This did not mean that there might not be instances where differentiation on gender lines may not be justified for purposes of certain rituals, as long as it did not amount to prejudice to any female descendent. ${ }^{106}$

102 At 555C/D - D/E.

103 At 555E.

104 At 555E/F.

105 At 554E - F/G.

106 At 55A - B. 
It was ruled, on the basis of the principle of equality (section 9 of the Constitution), that a female may inherit intestate. The rule of primogeniture as sanctioned by regulation 2(e) was found to be unconstitutional. ${ }^{107}$

\subsubsection{Shibi v Sithole ${ }^{108}$}

In Shibi v Sithole the deceased died intestate without leaving descendents, parents or grandparents. His nearest male relatives were his two cousins. He also was survived by his sister, but she was excluded in terms of the customary law. She sought an order declaring herself to be the sole heir in the estate of her brother. ${ }^{109}$

\subsubsection{Later Constitutional Court decision}

In the later Constitutional Court decision of Bhe $v$ Magistrate, Khayelitsha (Commission for Gender Equality as Amicus Curiae) Shibi v Sithole; SA Human Rights Commissioner $v$ President of $R S A^{110}$ there were two main issues to be decided. The first was the constitutional validity of section 23 of the BAA and the second concerned the constitutional validity of the principle of primogeniture in the context of customary law of succession. In this case the rule of primogeniture was attacked as being unconstitutional and in conflict with the interests of women and children.

The court found that the validity of the rules and principles of customary law depended on whether they were consistent with the Constitution and in particular the Bill of Rights. ${ }^{111}$ Section 23 was found to be a racist provision that was fundamentally unconstitutional. It was contrary to sections 9 and 10 of the

107 See also par [19] page 597 of the Constitution Court case.

108 Shibi v Sithole Case No 7292/01, 19 Nov 2003.

109 See par [21]-[28].

110 Supra n 20. Both the Bhe and Shibi cases were applications for confirmation of the High Court orders. South African Human Rights Commission and the Women's Legal Centre Trust furthermore contended that the whole of s 23 of the BAA, alternatively subs (1), (2) and (6) of s 23, had to be declared unconstitutional because of their inconsistency with s 9 , 10 and 28 of the Constitution.

111 Par [40], [41] and [46]. S 28 of the Constitution protects the rights of children. Par [52-54]. 
Constitution due to its blatant discrimination on grounds of race, colour and ethnic origin and its harmful effects on the dignity of people. ${ }^{112}$ Although the criticism was directly aimed at section 23(10) and the regulations made in terms thereof, it was clear that the subsections in section 23 read with the regulations, constituted a scheme of intestate succession whereby the legal system governing intestate succession was based on skin colour. ${ }^{113}$ This could not be justified. ${ }^{114}$

The second question concerned the validity of the principle of primogeniture. Langa $\mathrm{dcj}^{115}$ summarised the attack on customary law as follows:

The basis of the constitutional challenge to the official customary law of succession is that the rule of primogeniture precludes (a) widows from inheriting as the intestate heirs of their late husbands; (b) daughters from inheriting from their parents; (c) younger sons from inheriting from their parents, and (d) extra-marital children from inheriting from their fathers. ${ }^{116}$

The court found that customary law had been distorted in a manner that emphasised its patriarchal features while minimising its communitarian ones. ${ }^{117}$ The exclusion of women, and the notion of male domination were incompatible with the guarantee of equality in the Constitution ${ }^{118}$ and the principle of primogeniture violated the right to human dignity. ${ }^{119}$ The context in which the rule of male primogeniture, which forms the basis of customary law and inheritance, had changed ${ }^{120}$ did not necessarily correspond with an enforceable responsibility to support the family of the deceased. Although it was desirable to leave it to the Legislature to bring customary law in line with the Constitution, the courts had the responsibility to provide relief to parties who sought it.

112 Par [60] and [61].

113 Par [66].

114 Par [71]-[73]

115 At par [88].

116 See n 107-110 on page 620.

117 Par [89].

118 Par [91].

119 See also par [92]-[93].

120 Par [80 and [91]. 


\subsection{Administration of estates}

As seen above, different systems of administration of estates (based on race) existed before 2000. Before 6 December 2000, the winding up and administration of estates broadly could be divided into two categories. The Master had jurisdiction over all white, coloured and Indian estates as well as black testate estates ${ }^{121}$ and magistrates had jurisdiction over the intestate estates of blacks.

\subsubsection{Issues regarding the administration of estates}

This differentiation was pointed out in Moseneke $v$ The Master. ${ }^{122}$ The family applied to the Transvaal Provincial Division of the High Court for an order declaring unconstitutional the Master's refusal to register and administer the estate and ordering the Master to do so. The family's legal representatives successfully requested an order invalidating regulation 3(1) of the regulations promulgated under the BAA, which authorised magistrates to deal with intestate black estates. This order was granted but did, however, not deal with the section in the BAA which prohibited the Master of the High Court from dealing with intestate black estates. ${ }^{123}$

As a result, neither the Master nor a magistrate could deal with the intestate deceased estates of thousands of black Africans. The Constitutional Court dealt with the matter on an urgent basis. The Women's Legal Centre was admitted to this constitutional case as amicus curiae. The centre contended that in the case of intestate estates of deceased Africans, race, gender, and culture interacted in a way which discriminated indirectly against African widows. ${ }^{124}$

121 In terms of $s$ 23(9) of the BAA certain house property and land were excluded from testamentary disposition.

122 Supra n 93.

123 Par [9].

124 Par [17]. 
The court ordered that section 23(7)(a) of the BAA which excluded the Master of the High Court from any powers in connection with the estates of black Africans who died intestate, was inconsistent with the Constitution and invalid with immediate effect, but that the regulation would remain in place for two years to give Parliament a chance to harmonise and deracialise the laws dealing with deceased estates in an effective manner. ${ }^{125}$

In attempting to make a just and equitable order, the court did not consider intestate deceased estates specifically which devolved according to customary law. The Constitutional Court decided that any legislation that favours different systems of administration on grounds of race should be declared unconstitutional. ${ }^{126}$

It was found that both section 23(7) and regulation 3(1) imposed differentiation on the grounds of race, ethnic origin and colour and constituted unfair discrimination in terms of sections 9 and 10 of the Constitution and, furthermore, that the limitations posed by the provisions were not reasonable and justifiable in an open and democratic society based on equality, freedom and dignity. The court held that: ${ }^{127}$

- Section 23(7)(a) of the BAA was invalid with immediately effect from 6 December 2000 (in so far as it excluded the Master);

- The status of estates already completed were to be upheld;

- The declaration of invalidity of regulation 3(1) was suspended for two years. ${ }^{128}$ During the period of suspension the word 'shall' in regulation $3(1)$ is to be read as meaning 'may'). ${ }^{129}$

- Beneficiaries and black families of a deceased who left an intestate estate (which was not governed by customary law) had the choice where they wanted to report a deceased estate. ${ }^{130}$

125 Par [31] 2.

126 Par [24] and [25].

127 Par [31].

128 See par [31].

129 Par [31]. 
On 5 December 2002, and just before the two year window period expired, (i) the Administration of Estates Amendment Act 47 of 2002 and (ii) the Amendment of the Regulations for the Administration and Distribution of Estates, GN R1501 of 2002 were promulgated to give effect to the order in Moseneke.

In terms of these amendments, the Administration Act $^{131}$ provided for service points where officials could act on behalf of and under direction of the Master and the power to appoint a representative under section 18(3) in estates with a value of not more than R50 000 was delegated. The latter estates were to be administered by the magistrates, but under supervision of the Master. ${ }^{132}$ All other estates, excluding those that devolve under customary law, had to be reported to the Master. ${ }^{133}$ The intestate estates of black persons that had to devolve under customary law still were administered by magistrates.

\subsubsection{Issues regarding the administration of estates surfaced again in 2004}

On 15 October 2004, the Constitutional Court ruled in Bhe v Magistrate, Khyayelitsha (Commission for Gender Equality as Amicus Curiae); Shibi $v$ Sithole; South Africa Human Rights Commission v President of South Africa ${ }^{134}$ that all discrimination in and differentiation of the administration systems should cease. ${ }^{135}$ The Bhe case went even further than the Moseneke case. In Bhe it was declared that section 23 was, as from 15 October 2004, in its entirety, inconsistent with the Constitution. ${ }^{136}$

130 With the Master or a magistrate.

131 S 2A.

$132 \mathrm{~S} 2 \mathrm{~A}$ of the Administration Act.

$133 \mathrm{~S} 4(1 \mathrm{~A})$ of the Administration Act.

134 Supra $\mathrm{n} 20$.

135 Par [136] 1.

136 See par [130], [132] and [136] 2. 
Langa dcj found that it contravened sections 9(3), 10 and 28 of the Constitution and that such discrimination was not justifiable in terms of section 36 of the Constitution. ${ }^{137}$

After Bhe's case, Justice College ${ }^{138}$ compiled a manual to facilitate a uniform process in terms of which estates of all people who died after 27 April 1994 had to be administered by the Master. ${ }^{139}$

\subsubsection{Repeal Act}

On 12 April 2006 the Repeal of the Black Administration Act and Amendment of Certain Laws Act 28 of 2005 came into operation ${ }^{140}$ which incrementally repeals the provisions of the BAA and the Administration Act. This was to give effect to the judgment in Bhe.

In terms of the preamble to the Repeal Act, the BAA is stated to be regarded as a law that:

- is contrary to the values set out in the Constitution, particularly section 1 and the Bill of Rights in chapter 2 thereof;

- is reminiscent of past divisions and discrimination; and

- ought to be repealed as a matter of the utmost urgency.

This Repeal Act repealed certain sections of the Administration Act to give the Master of the High Court jurisdiction over property of all minors, including those whose position is governed by the principles of customary law ${ }^{141}$ and to provide for matters concerned therewith.

137 Par [68].

138 Cronjé 2004 Policy and Procedure Manual.

139 As a direct result of Bhe's case the Repeal of the Black Administration Act and Amendment of Certain Laws Act 28 of 2005 was promulgated on 12 April 2006.

140 GG 28726 of 12 April 2006. The Act was amended by Repeal of the Black Administration Act and Amendment of Certain Laws Act 8 of 2006.

141 S 2 amended s 4. 
Section 1(1)-(8) of the Act repealed the BAA and the regulations pertaining to the BAA in toto. The result is now that all estates are now to be treated the same.

The Judicial Matters Amendment Act 22 of 2005 commenced on 11 January 2006. Section 2 amended the Administration Act amending the definition of 'Master' ${ }^{142}$ and section 3 provides that the Chief Master ${ }^{143}$ is subject to control, direction and supervision of the Minister.

Further amendments were made by a second Act - the Repeal of the Black Administration Act and Amendment of Certain Laws Amendment Act 8 of 2006. ${ }^{144}$ The date of commencement of the second Repeal Act was 30 July 2006 and it amended the first Repeal Act (28 of 2005) by substituting the date '31 July 2006' wherever it occurs in the first Act with '30 September 2007'. 145

\section{Conclusion}

Although customary law enjoys constitutional recognition, its rules are not allowed to be in conflict with the Constitution.

Even though the SALRC had been considering the reform of customary law of succession and inheritance for more than a decade, nothing came of its proposals as a consequence of which the courts were forced to provide

142 'Master' is now defined as the Master, Deputy Master or Assistant Master of a High Court appointed under s 2 who has jurisdiction in respect of that matter, property or estate and who is subject to the control, direction and supervision of the Chief Master.

143 Amendment of s 2 - Chief Master: S 2(1) now provides that, subject to subs 2(2) (ie relevant degree required or Minister placing temporary Master in vacated position) and the public service laws, the Minister appoints a Chief Master of the High Courts; appoints a Master of the High Court for the area of jurisdiction of each High Court; and may, in respect of each area, appoint one or more Deputy Masters and Assistant Masters, who may, subject to the control, direction and supervision of the Master, do anything which may lawfully be done by the Master. The Chief Master is subject to the control, direction and supervision of the Minister; is the executive officer of the Masters' offices; and shall exercises control, direction and supervision over all the Masters.

144 GG No 29067 of 25 July 2006.

145 See $\mathrm{s} 1$. 
appropriate relief. This lead to a number of principles of customary law being declared unconstitutional and, consequently, invalid. ${ }^{146}$

The current situation regarding intestate succession is that the Bhe case has far-reaching implications for customary law of intestate succession and is considered a victory for African women and their children. The court had no choice but to provide relief until such time as the legislature enacts a lasting solution. As far as the intestate succession is concerned, the Bhe case extends the Intestate Succession Act to all persons in South Africa, including those adhering to a system of customary law. In future, no distinction will be made between legitimate and illegitimate children, between a first born son and other siblings or between men and women.

As section 1(4)(b) of the Intestate Succession Act was declared invalid, section 1 of the Act in future would apply to the intestate deceased estates of persons that formerly would have been governed by section 23 of the BAA. If a deceased is survived by more than one spouse, in the application of sections $1(1)(c)(i)$ and 1(4)(f) special provisions would apply. ${ }^{147}$

Notwithstanding the judgments referred to above, the Intestate Succession Act has not been amended by the legislature. ${ }^{148}$ The recommendations of the SALRC also have lead to nothing. ${ }^{149}$

146 Kerr supra n 72 discusses other aspects that were not dealt with in case law such as oral dispositions, testamentary succession in two systems of law at the same time etc. These aspects do not fall within the scope of this research.

147 See par [125] and par [136] 7 of Bhe.

148 Recently it was decided in Gory v Kolver 2006 (5) SA 145 (T) and Case CCT 28/06 decided on 23 November 2006 that a surviving partner in a permanent same-sex life partnership in which the partners had undertaken reciprocal duties of support can inherit intestate. The Constitutional Court ruled subs 1(1) of the Intestate Succession Act to be unconstitutional in that it does not make provision for such surviving partners to also inherit intestate from their life-long partners. This judgment will have an effect on all people whether they live under customary law or not. See also the Civil Unions Act 17 of 2006.

149 In respect of customary law of succession the SALRC stated that it had revised the original Draft Bill to now cater for the following: The modification of the customary law of succession so as to provide for the devolution of certain property in terms of the law of intestate succession; for house property to be disposed of in terms of a will; to protect property rights in certain customary marriages. See par 1.7.2. Provision is made for the disposition of property allotted or accruing to a wife in a customary marriage. The proposed draft Bill is intended to protect the interest of a wife and children on the death of 
The current situation regarding administration of estates is that all estates, including intestate estates of black persons that have to devolve under customary law, have to be administered by the Master. This is the beginning of a unified system in terms of which all estates must be reported to the Master. Magistrates will no longer have the responsibility to supervise and administer customary estates.

(i) All estates that were reported before 15 October 2004 have to be finalised in the way that they were reported.

(ii) From 15 October 2004 all property, irrespective of whether it is house property or quitrent land, may be disposed of by means of a will.

(iii) A black person's freedom of testation is similar to that of any other person in terms of the common law.

The SALRC published a Discussion Paper on the Administration of Estates in October 2005. ${ }^{150}$ They recommended that a unitary system for the administration of all estates must be applied following the Bhe decision. They propose that all estates should be administered under the supervision of the Master and that beneficiaries should have a choice to report an estate to the Master or a service point with jurisdiction. All estates of people who die leaving a will or property must be reported. ${ }^{151}$

Although the legislature repealed the BAA and then proceeded to effect minor amendments to the relevant legislation ${ }^{152}$ (the Administration Act) in order to

the family head; the right to inherit would be extended to needy family members and that children adopted in terms of customary law and children with a man other than the husband as premarital progenitor inherit on the same basis as children adopted in terms of the Child Care Act 74 of 1983 and to amend the Intestate Succession Act so as to protect the rights of certain children; to protect a widow whose customary marriage was dissolved by the civil marriage of her husband with another woman; to amend the Maintenance of Surviving Spouses Act 27 of 1990 so as to provide for a claim for maintenance by certain wives or spouses in customary marriages.

150 SALRC 2005 Administration of Estates. The closing date for comments was 18 Nov 2005 and the comments are now available in a 167 page document.

151 See the Report for detailed discussion on several other aspects.

152 See discussion above. 
give effect to the judgments regarding the unconstitutionality of certain principles, the current situation regarding customary law of succession and inheritance remains unsatisfactory and inadequate to the extent that there is no proper legislation in place and there might be millions of black people who prefer a choice of law rule. ${ }^{153}$ The judgments which recognised gender equality and equal shares for all children in cases of black intestate estates, are welcomed. The repeal of the BAA as far as there was discrimination between black and white estates also is judicious.

153 For a critical evaluation of the current situation regarding the choice of law rules and succession see Kerr supra $\mathrm{n} 72$. 


\section{Bibliography}

Bekker and Maitufi 1992 JJS

Bekker JC and Maithufi IP “The dichotomy between 'official customary law' and 'non-official customary law'" 1992 (1) Journal for Juridical Science 47

\section{Bekker et al Introduction}

Bekker JC, Labuschagne JMT and Vorster LP Introduction to Legal

Pluralism in South Africa Part I: Customary Law (LexisNexis Butterworths

Durban 2002)

Cronjé 2004 Master's Policy and Procedure Manual

Cronjé T Master's Policy and Procedure Manual: Administration of Intestate

Deceased Estates at Service Points (SALRC Pretoria 2004)

Corbett et al Succession

Corbett MM, Hofmeyr G and Kahn E The Law of Succession in South

Africa $2^{\text {nd }}$ ed (Juta Cape Town 2001)

De Waal and Schoeman-Malan Succession

De Waal MJ and Schoeman-Malan MC Introduction to the Law of Succession $3^{\text {rd }}$ ed (Juta Cape Town 2003)

Kerr 2006 SPECULUM JURIS

Kerr AJ "The Constitution, the Bill of Rights, and the Law of succession 2006 (1) SPECULUM JURIS 1

Kerr 2005 SPECULUM JURIS

Kerr AJ "The Constitution, the Bill of Rights, and the Law of succession (1)" 2005 (2) SPECULUM JURIS 181

Mbatha 2002 SAJHR

Mbatha L "Reforming the Customary Law of Succession" 2002 SAJHR 262 
Olivier et al Indigenous Law

Olivier NJJ, Bekker JC, NJJ Olivier (Jnr), Olivier WH Indigenous Law (LexisNexis Butterworths Durban 2004)

Palmer Mixed jurisdictions

Palmer VV Mixed jurisdictions worldwide: The third legal family (Cambridge University Press Cambridge 2001)

SALC 1998 Report on Customary Marriages

South African Law Commission Report on Customary Marriages (Project 90) 1998

SALRC 2005 Administration of Estates South African Law Reform Commission Administration of Estates Discussion Paper 110 (Project 134) 2005

SALRC 2004 Customary Law of Succession South African Law Reform Commission Customary Law of Succession Discussion Paper 93 (Project 90) 2004

SALRC 2003 Draft Interim Report South African Law Reform Commission Draft Interim Report on the Review of the Black Administration Act 38 of 1927 (Project 90) 2003

SALRC 2001 Customary Law: Administration of Estates South African Law Reform Commission Customary Law: Administration of Estates Discussion Paper 95 (Project 90) 2001

SALRC 2000 Customary Law: Succession Discussion South African Law Reform Commission Customary Law: Succession Discussion Paper 93 (Project 90) 2000 
SALRC 1999 Harmonisation of the Common Law and Indigenous Law South African Law Reform Commission The Harmonisation of the Common Law and Indigenous Law: Report on Conflicts of law (Project 90) 1999

Van der Burght and Ebben Nederland Erfrecht Van der Burght G and Ebben EWJ Het Nederlands Burgerlijk Recht Erfrecht $10^{\text {th }}$ ed Vol 5 (Kluwer Deventer 2004)

Van der Merwe and Rowland Succession Van der Merwe NJ and Rowland CJ South Africa Law of Succession $6^{\text {th }}$ ed (JP van der Walt Pretoria 1990)

\section{Register of legislation}

Administration of Estates Act 66 of 1965

Administration of Estates Amendment Act 47 of 2002

Amendment of the Regulations for the Administration and Distribution of

Estates GN R1501 of 2002

Black Administration Act 38 of 1927

Black Areas Land Regulations Proclamation R188 of 1969

Child Care Act 74 of 1983

Citation of Constitutional Laws Act 5 of 2005

Civil Unions Act 17 of 2006

Constitution of the Republic of South Africa 1996

Constitution of the Republic of South Africa Act 200 of 1993

Customary Law of Succession Amendment Bill 109 of 1998

Government Gazette no 28726 of 12 April 2006

Government Gazette no 29067 of 25 July 2006

Intestate Succession Act 1981 of 1987

Judicial Matters Amendment Act 22 of 2005

Land Tenure Rights Act 112 of 1991

Law of Succession Amendment Act 43 of 1992

Maintenance of the Surviving Spouses Act 27 of 1990

Marriage and Matrimonial Property Amendment Act 3 of 1988 
Matrimonial Property Act 88 of 1984

Promotion of Equality and Prevention of Unfair Discrimination Act 4 of 2000

Recognition of Customary Marriage Act 120 of 1998

Regulations for the Administration and Distribution of the Estates of Deceased

Blacks GN R200 of 1987

Repeal of the Black Administration Act and Amendment of Certain Laws Act 28 of 2005

Repeal of the Black Administration Act and Amendment of Certain Laws Act 8 of 2006

Wills Act 7 of 1953

\section{Register of court cases}

Bhe and Others v Magistrate, Khayelitsha, and Others 2004 (1) BCLR 27 (C); 20042 SA 544 (C)

Bhe v Magistrate, Khayalitsha; Shibi v Sithole; South African Human Rights Commission v President of the Republic of South Africa 20051580 (CC) Fraser v Children's Court, Pretoria North and Others 19972 SA 261 (CC) Gory v Kolver NO and Others 2006 (5) SA 145 (T) Gory v Kolver NO and Others CCT 28/06 23 November 2006 Minister of Education v Syfrets Trust Ltd NO 20064 SA 205 (C) Moseneke and Others $v$ The Master and Another 20012 SA 18 (CC) Mthembu $v$ Latsela and Another 19972 SA 936 (T); 19982 SA 675 (T); 20003 SA 867 (SCA).

Nwamitwa v Phillia and Others 20053 SA 536 (T)

President of the Republic of South Africa and Anor v Hugo 19974 SA 1 (CC) Shibi v Sithole Case No 7292/01 (TPD) unreported case 19 November 2003 Zondi v President of the Republic of South Africa and Others 20002 SA 49 (N)

\section{Register of Internet resources}

Barratt and Snyman 2002 LLRX http://www.Ilrx.com/ 11 Dec Barratt A and Snyman P "Researching SA Law" 2002 LLRX 1 October [Found on internet] http://www.Ilrx.com/features/southafrica.htm [Date of use 11 December 2006] 
Tetley 1999 ULR http://www.unidroit.org/ 20 Apr

Tetley W "Mixed Jurisdictions: Common law v Civil law" 1999 Uniform Law Review [Found on internet]

http://www.unidroit.org/english/publications/review/ articles/1999-3.htm

[Date of use 20 April 2007]

\section{List of conventions}

European Convention on the legal status of children born out of wedlock 1975 International Convention on the Elimination of All Forms of Discrimination against Women 1993

\section{List of abbreviations}

$\begin{array}{ll}\text { a } & \text { article(s) } \\ \text { BAA } & \text { Black Administration Act } \\ & \text { International Convention on the Elimination of All forms of } \\ \text { ch } & \text { discrimination against Women } \\ \text { cl } & \text { chapter(s) } \\ \text { par } & \text { clause(s) } \\ \text { reg } & \text { paragraph(s) } \\ \text { s } & \text { regulation(s) } \\ \text { SALC } & \text { section(s) } \\ \text { SALRC } & \text { South African Law Commission } \\ \text { sch } & \text { South African Law Reform Commission } \\ \text { subs } & \text { schedule(s) } \\ \end{array}$

